\title{
Molecular and Bacteriological Examination of Cow Milk in Coliform Mastitis
}

\author{
J.R. Kavitha and T. Devasena \\ Lecturers, Department of Biotechnology, Mother Teresa Women's University, Kodaikanal, India \\ Assistant Professor, Anna University, Chennai, India
}

\begin{abstract}
In the present study, 20 samples of milk of cow, pasteurized milk were collected from the local market and were analyzed for microbial count and IMViC tests to determine the coliform load in the sample. Further, the presence of E. coli (KC795687) was confirmed by using PCR and 16srna sequencing. Majority of the milk samples of different origin were found to be contaminated by the coliform group of bacteria. The samples were found to be positive for E. coli by PCR analysis and 16srna sequencing. Pasteurized milk samples did not showed presence of E. coliby PCR, but they showed considerable count of bacterial growth by total plate count method. The results indicated that analyzed milk could contribute a potential risk for public health in the cases that it was consumed or used in the production of dairy products without being pasteurized or being subjected to a sufficient heat process. Moreover, PCR is less labor intensive, more rapid for bacterial identification and it further confirmed in 16srna sequencing.
\end{abstract}

Key Words; PCR-Polymeric chain Reaction, IMViC-Indole methyl red, vogues proskaur, citrate utilization test.

\section{Introduction}

Mastitis is the most economically significant disease of dairy animals. This condition is widespread in dairy herds and is associated with a significant reduction in milk yield, increased costs of production and deteriorated milk quality. These costs are borne directly by milk producers and indirectly by the consumers of dairy products. The disease also results in partial or complete damage to udder tissues and decreases the productive life span of the animal.

Mastitis is caused by many bacteria, which include the coliform group (specifically Escherichia coli, Enterobacter, Klebsiella species), Streptococci, Staphylococci, Corynebacteria, Pasteurella, Mycoplasma, Leptospira, Yersinia, Mycobacteria, Pseudomonas, Serratia and other organisms like fungi, yeasts and virus. (Kotowshi, 1988 and Gonzalez et al., 1980).

The most important species in the coliform group of organisms. Escherichia coli (E.coli), a rod-shaped member of the coliform group, can be distinguished from most other coliforms by its ability to ferment lactose at $44^{\circ} \mathrm{C}$, and by its growth and color reaction on certain types of culture media. It is the lactose fermenter and produces pink colonies in Macconkey agar. When cultured on an EMB plate, a positive result for E.coli is a metallic green media with dark purple colonies. Unlike the general coliform group, E.coli are almost exclusively of fecal origin and their presence is thus an effective confirmation of faecal contamination. Typically, E.coli are about $11 \%$ of the coliforms in human faeces. (Burns et al., 1996).

Optimal growth of E.coli occurs at $37^{\circ} \mathrm{C}$, but some laboratory strains can multiply at temperatures of up to $49^{\circ} \mathrm{C}$. Growth can be driven by aerobic or anaerobic respiration, using a large variety of redox pairs, including the oxidation of pyruvic acid, formic acid, hydrogen and amino acids, and reduction of substrates such as oxygen, nitrate, dimethyl sulfoxide and trimethylamine N-oxide. (Bradley et al., 2001).

Mastitis is an inflammation of under which is mainly caused by coliforms and other micro organism. It is a most economically important disease in cattle's. It is mainly caused by E.coli in dairy cattle's. The major reason for the disease is environmental factors like contaminated water. In the present study virulent. E.coli strains were isolated from Bovine mastitis and the virulent genes were identified using Multiplex PCR, and 16s rna sequencing to identify the coliform organisms. Identification of Virulent E. coli from Bovine mastitis was carried out in Mother Teresa Women's University, kodaikanal.

Identification of Virulent E.coli from Bovine mastitis was carried out in Mother Teresa Women's University, Kodaikanal, and 2008 - 2009. The part of the work was carried out in Tamil Nadu Veterinary and Animal Science University, Chennai. The results are produced and discussed in this chapter.

The aim of this project is the isolation of E.coli from the mastitis milk sample. Mac conkey agar and Eosine Methylene blue agar were used in the preliminary identification of E. coli further identification was done by biochemical and sugar fermentation test.Mastits is an inflammation of udder which is mainly caused by coliforms and other organisms. It is a major disease caused by E.coli in dairy cattles. 10 isolates of E. coli were obtained from 20 samples of mastitis milk showing $50 \%$ incidence rate. 


\section{Materials and methods}

20 Milk samples were collected from mastitis affected cows. The samples were inoculated in Triptose soya broth, After an incubation period of 4-6 hours, the samples were streaked on differential media namely Mac Conkey agar, Eosine Methylene blue agar.In Mac Conkey agar, out of 20 samples 15 samples produced pink colour colonies. In Eosine Methylene blue agar out of 15 samples 10 sample produced colonies with metallic sheen.Futher identification of E.coli isolates was done by biochemical and sugar fermentation test using Enterbacteriaceae rapid kit.Simultanoushly antibiotic sensitive test was also done to identify the sensitivity pattern of the E.coli isolates. PCR was done for the detection of virulence genes. The coliform mastitis further confirmed by 16 srna sequencing.

\section{Tryptose Soy Agar Culture}

Tryptose soy agar was used to isolate coliforms from Mastitis milk sample. E.coli is a type of coliform. In the present study colonies were isolated without any contamination. This result is supported by previous work done to isolate E.coli from raw milk and milk products in relation to public health sold under market condition at Tandojam (Ahmed and Sailam, 1991; Sharma and Joshi, 1992; Adesiyum, 1994n and Soomro et al., 2002) where they isolated the micro organism from milk using Tryptose soy agar, they also got well isolated colonies.

\section{Mac conkey agar}

Mac conkey agar is used to isolate coliform. If the organism is coliform they ferment the lactose in the medium and form pink colour colonies. In the present work, out of 20 Mastitis milk samples collected, 15 samples were produced ink colour colony indicating the presence of coliform. This result is supported by previous work done to isolate E.coli from raw milk products in relation to public health sold under market condition at Tandojam (Ahmaed and Sailam, 1991; Sharma and Joshi, 1992; Adesiyum, 1994n and soomro et al; 2002) where they isolated smooth, circular pink colour colonies with spreading growth.

\section{Eosin Methylene Blue (EMB) Agar}

Eosin Methylene Blue (EMB) Agar is used for identification of micro organism. E. coli produced Metallic sheen colour colons in Eosin Methylene Blue (EMB) Agar. In the present study 15 isolates which produced pink colour colonies in Mac conkey agar were streaked on EMB agar, Out of 15 isolates 10 isolates produced Metallic Sheen colour colonies indicating the presence of E. coli. This work is supported by previous work done to isolate E. coli from raw milk and milk products in relation to public health sold under market condition at Tandojam (Ahmed and Sailam, 1991; Sharma and Joshi, 1992; Adesiyum, 1994n and Soomro et al., 2002) where the E. coli colonies were identified using Eosin Methylene Blue (EMB) Agar, E.coli produced Metallic sheen colour colonies.

\section{Gram Staining}

Gram staining is used for identification of Gram positive and Gram negative organism. E.coli is a gram negative rod. Shaped bacterium. In the present study the 10 isolates were subjected to gram staining all the isolates were found to be gram negative rods. This work is supported by previous work done to identify micro organism (Cruickshank et al., 1994) where they identified Ecoli as gram negative rods.

\section{Inoculation into Broth:}

In the laboratory the milk sample was inoculated into tryptose soy broth under sterile condition. After inoculation, the test tube was incubated at $37 \mathrm{oC}$ for overnight. (Cruickshank et al., 1975).

\section{Inoculation into Tryptose Soy Agar:}

A loopful of culture from the tryptose soy broth was streaked onto tryptose soy agar plates. After inoculation the plates were incubated at $37 \mathrm{oC}$ overnight. (Cruickshank et al., 1975).

\section{Noculation into Agar Plates:}

Well isolated colonies from the TSA plates were streaked onto the following agar plates,

-Mac Conkey Agar

-Eosin Methylene Blue Agar. (Cruickshank et al., 1975). 


\section{Biochemical Tests \\ Indole Test}

A loop full of culture from $24 \mathrm{~h}$ growth medium was inoculated in Tryptone medium and incubated at $37^{\circ} \mathrm{C}$ for $24 \mathrm{~h}$. After incubation $0.5 \mathrm{ml}$ of Kovac's reagent was added to it and observed for the ring formation. (Cruickshank et al., 1975).

\section{Methyl Red Test}

Sterile MR broth was inoculated with the isolate and incubated at $37^{\circ} \mathrm{C}$ for $24-48$ hours after incubation, methyl red solution was added and shaken well. (Cruickshank et al., 1975).

\section{Voges Proskauer Test}

VP broth was inoculated with cultures and tubes were incubated at $37^{\circ} \mathrm{C}$ for $24-48$ hours. Baritt's reagent was added in all test tubes and the result was observed. (Cruickshank et al., 1975).

\section{Citrate Utilisation}

The test culture was inoculated into Simmons citrate medium and inoculated at $37^{\circ} \mathrm{C}$ for 24 hours and observed for colour change (Cruickshank et al., 1975).

\section{Eijkman Test}

1. Durham's tube was placed inside the test tubes containing Mac conkey broth. Care should be taken that there should be no air bubbles.

2. Inoculate the isolate into the sterilized test tubes.

3. Incubated for $24-48$ hours at $44^{\circ} \mathrm{C}$ Formation of air bubbles inside the Durhams tube indicated the positive results. (Cruickshank et al., 1975)..

\section{Sugar Fermentation Test}

The cultures were incubated in the respective sugar medium (glucose, sucrose. Lactose, maltose, mannitol, mannose, raffinos, xylose, sorbitiol, trehalose, fructose) and incubated at $37 \mathrm{C}$ over night. After incubation, Andrads indicator was added to the culture tubes. Red colour was formed as a result of the production of acid and gas confirm the positive reaction. (Cruickshank et al., 1975)..

\section{Antibiogram Test}

The $8 \mathrm{~h}$ bacterial culture was spread on Trypose soy agar using a sterile swab. The plates were dried and then the antibiotic disc were placed by means of a sterile forceps and incubated at $37^{\circ} \mathrm{C}$ overnight. Clear zone around the antibiotic disc indicated that the organism is sensitive. The diameter of each zone of inhibition was measured, recorded and interpreted according to the zone size interpretative charts (Cruickshank et al., 1975).

TABLE - 1:

ANTIBIOTIC DISC WITH STANDARD CONC

\begin{tabular}{|c|c|c|}
\hline S. No & ANTIBIOTICS & STRENGTH \\
\hline 1 & Gentamycin (G) & $10 \mathrm{mcg}$ \\
\hline 2 & Amoxyclav (Ac) & $30 \mathrm{mcg}$ \\
\hline 3 & Erythromycin (E) & $15 \mathrm{mcg}$ \\
\hline 4 & Trimethoprim (Tr) & $30 \mathrm{mcg}$ \\
\hline 5 & Ciprofloxacin (cf) & $5 \mathrm{mcg}$ \\
\hline 6 & Norfloxacin(Nx) & $10 \mathrm{mcg}$ \\
\hline 7 & Ampicillin(A) & $10 \mathrm{mcg}$ \\
\hline 8 & Azithromicin(AZ) & $30 \mathrm{mcg}$ \\
\hline 9 & Enrofloxacin & $10 \mathrm{mcg}$ \\
\hline
\end{tabular}

\section{The Protocol of Sequencing Service}

1. Sequencing Kit: ABI PRISM® BigDyeTM Terminator Cycle Sequencing Kits

2. Sequencer: ABI PRISM® 3730XL Analyzer (96 capillary type) (Over 20)

3. PCR machine: MJ Research PTC-225 Peltier Thermal Cycler 


\section{Sequencing protocol}

Sequencing reactions were performed in a MJ Research PTC-225 Peltier Thermal Cycler using a ABI PRISM ${ }^{\circledR}$ BigDyeTM Terminator Cycle Sequencing Kits with AmpliTaq ${ }^{\circledR}$ DNA polymerase (FS enzyme) (Applied Biosystems), following the protocols supplied by the manufacturer. Single-pass sequencing was performed on each template using [Universial or what you selected] primer. The fluorescent-labeled fragments were purified from the unincorporated terminators with an ethanol precipitation protocol. The samples were resuspended in distilled water and subjected to electrophoresis in an ABI 3730xl sequencer (Applied Biosystems).

\section{Primer information:}

\begin{tabular}{|c|l|l|l|l|}
\hline & Primer Name & Type & Type2 & Sequence (5 to 3) \\
\hline 1 & $518 \mathrm{~F}$ & Universal & Forward & CCAgCAgCCgCggTAATACg \\
\hline 2 & $800 \mathrm{R}$ & Universal & Reverse & TACCAgggTATCTAATCC \\
\hline 3 & $27 \mathrm{~F}$ & Universal & Forward & AgAgTTTgATCMTGGCTCAg \\
\hline 4 & $1492 \mathrm{R}$ & Universal & Reverse & TACggYTACCTTgTTACgACTT \\
\hline
\end{tabular}

Note:

Primer $1 \& 2$ for Sequencing Reference.

Primer $3 \& 4$ for PCR Amplification

\section{Analysis Procedure}

\section{Preparation Of Template Dna}

It is important to use a pure cultivated bacterium for identification. Colonies are picked up with a sterilized toothpick, and suspended in $0.5 \mathrm{~m} \ell$ of sterilizes saline in a $1.5 \mathrm{~m} \ell$ centrifuge tube. Centrifuged at $10,000 \mathrm{rpm}$ for $10 \mathrm{~min}$. After removal of supernatant, the pellet is suspended in $0.5 \mathrm{~m} \ell$ of instagene Matrix (BioRad, USA). Incubated $56^{\circ} \mathrm{C}$ for $30 \mathrm{~min}$ and then heated $100^{\circ} \mathrm{C}$

For $10 \mathrm{~min}$. After heating, supernatant can be use for PCR.

\section{PCR}

Add $1 \mu l$ of template DNA in $20 \mu l$ of PCR reaction solution. Use 27F/1492R primers for bacteria, and then perform 35 amplification cycles at $94^{\circ} \mathrm{C}$ for $45 \mathrm{sec}, 55^{\circ} \mathrm{C}$ for $60 \mathrm{sec}$, and $72^{\circ} \mathrm{C}$

For $60 \mathrm{sec}$. DNA fragments are amplified about $1,400 \mathrm{bp}$ in the case of bacteria. Include a positive control (E.coli genomic DNA) and a negative control in the PCR.

\section{Purification Of Pcr Products}

Remove unincorporated PCR primers and dNTPs from PCR products by using Montage PCR Clean up kit (Millipore).

\section{Sequencing.}

The purified PCR products of approximately 1,400 bp were sequenced by using 2 primers as described (Primer Name File). Sequencing were performed by using Big Dye terminator cycle sequencing kit (Applied biosystems, USA). Sequencing products were resolved on an Applied Biosystems model 3730XL automated DNA sequencing system (Applied biosystems, USA).

\section{Result and Discussion:}

The Coliform mastitis is caused by a group of coliform organisms E. coli is one of the most important bacterium of coliform group that causes mastitis in Cattle. Ecoli isolates were isolated by culturing in Eosine Methylene blue agar and in Mac Conkey agar. The isolates were confirmed by different Biochemical Tests and Sugar fermentating Tests. By using alkaline lysis method plasmid was isolated and the pathogenicity of E. coli was confirmed using PCR and 16srna sequencing were observed and it reveals the virulence of E. coli that caused mastitis. 
BIO - CHEMICAL TEST

\begin{tabular}{|c|c|c|c|c|c|}
\hline Isolates & $\begin{array}{l}\text { Eijkman's } \\
\text { Test }\end{array}$ & Indole & MethyIRed & $\begin{array}{l}\text { Voges } \\
\text { Proskauer }\end{array}$ & $\begin{array}{l}\text { Citrate } \\
\text { Utilisation }\end{array}$ \\
\hline 1 & + & + & + & - & - \\
\hline 2 & + & + & + & - & - \\
\hline 3 & + & + & + & - & - \\
\hline 4 & + & + & + & - & - \\
\hline 5 & + & + & + & - & - \\
\hline 6 & + & + & + & - & - \\
\hline 7 & + & + & + & - & - \\
\hline 8 & + & + & + & - & - \\
\hline 9 & + & + & + & - & - \\
\hline 10 & + & + & + & & - \\
\hline
\end{tabular}

+ Positive - Negative

SUGAR FERMENTATION TEST

\begin{tabular}{|c|c|c|c|c|c|}
\hline Samples & Arabinose & Sucrose & Lactose & Xylose & Cellobiose \\
\hline 1 & + & + & + & + & + \\
\hline 2 & + & + & + & + & - \\
\hline 3 & + & + & + & + & + \\
\hline 4 & + & + & + & + & + \\
\hline 5 & + & + & + & + \\
\hline 6 & + & + & + & + & + \\
\hline 7 & + & + & + & + \\
\hline 8 & + & + & + & + \\
\hline
\end{tabular}

SUGAR FERMENTATION TEST (Enterobacteriaceae Kit).

\begin{tabular}{|c|c|c|c|c|}
\hline Arabinose & Sucrose & Lactose & Xylose & Cellobiose \\
\hline+ & + & + & + & - \\
\hline
\end{tabular}

\section{+ Positive - Negative}

After an incubation period of 4-6 hours, the samples were streaked on differential media namely Mac Conkey agar, Eosine Methylene blue agar.In Mac Conkey agar, out of 20 samples 15 samples produced pink colour colonies. In Eosine Methylene blue agar out of 15 samples 10 sample produced colonies with metallic sheen 

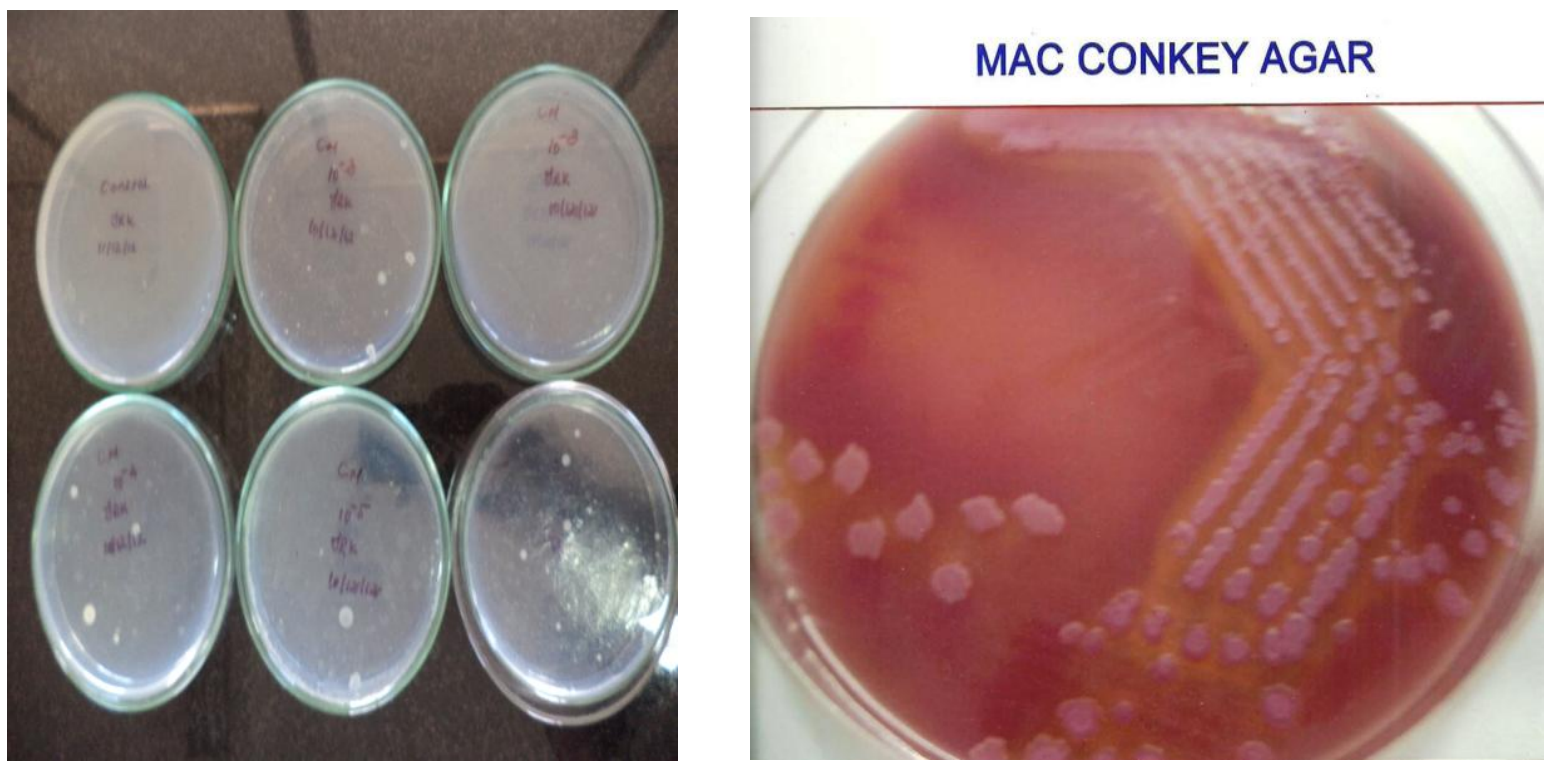

EOSIN METHYLENE BLUE AGAR

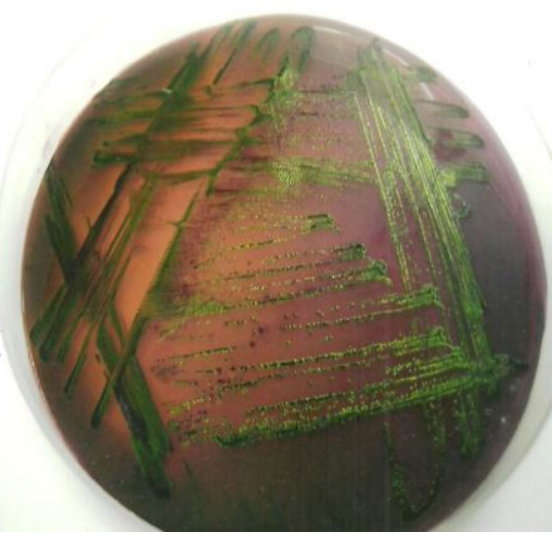

TRYPTOSE SOY AGAR

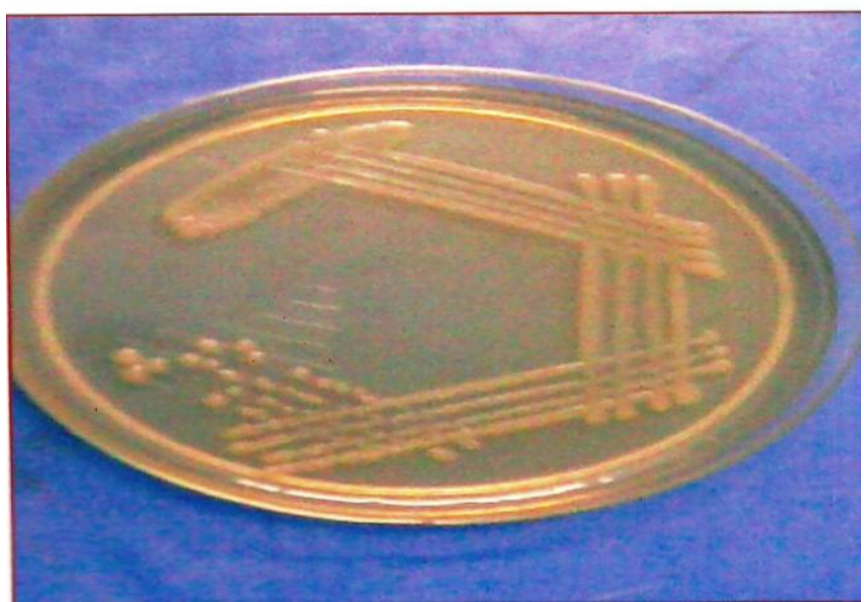

Antibiogram Test

\begin{tabular}{|c|l|c|c|c|}
\hline S. No & \multicolumn{1}{|c|}{ Antibiotics } & Resistance & Intermediate & Sensitive \\
\hline 1 & Gentamicin (G) & - & 5 & 5 \\
\hline 2 & Amoxyclav (Ac) & - & 3 & 7 \\
\hline 3 & Erythromycin (E) & - & 5 & 5 \\
\hline 4 & Trimethoprim (Tr) & - & 2 & 8 \\
\hline 5 & Ciprofloxacin (Cf) & - & - & 10 \\
\hline 6 & Norfloxacin (Nx) & 9 & 1 & - \\
\hline 7 & Ampicillin (A) & 10 & - & - \\
\hline 8 & Azithromicin (Az) & - & 4 & 6 \\
\hline 9 & Enrofloxacin (En) & - & - & 10 \\
\hline
\end{tabular}

10 Milk samples were collected from mastitis affected cows. The samples were inoculated in Triptose soya broth, Futher identification of E.coli isolates was done by biochemical and sugar fermentation test using Enterbacteriaceae rapid kit.Simultanoushly antibiotic sensitive test was also done to identify the sensitivity pattern of the E.coli isolates. 
Genera $f$ Bacteria isolated from the Coli form Mastitis Cow Milk Sample In 16srna

\begin{tabular}{|c|c|c|c|c|c|c|c|c|c|c|c|c|c|}
\hline $\begin{array}{l}\text { Sta } \\
\mathrm{rt}\end{array}$ & $\begin{array}{l}\text { En } \\
d\end{array}$ & Description & $\mathrm{AC}$ & $\begin{array}{l}\text { Leng } \\
\text { th }\end{array}$ & $\begin{array}{l}\text { Star } \\
\mathrm{t}\end{array}$ & End & $\begin{array}{l}\mathrm{Bi} \\
\mathrm{t}\end{array}$ & $\begin{array}{l}\mathrm{Ra} \\
\mathrm{w}\end{array}$ & $\mathrm{Ev}$ & $\begin{array}{l}\mathrm{Ma} \\
\text { tch }\end{array}$ & $\begin{array}{l}\text { Tot } \\
\text { al }\end{array}$ & $\begin{array}{l}\text { Pct } \\
(\%\end{array}$ & strand \\
\hline 1 & $\begin{array}{l}14 \\
49\end{array}$ & $\begin{array}{l}\text { Escherichia } \\
\text { coli W } \\
\text { complete } \\
\text { genome }\end{array}$ & $\begin{array}{l}\text { CP002 } \\
967.1\end{array}$ & $\begin{array}{l}4897 \\
452\end{array}$ & $\begin{array}{l}224 \\
272\end{array}$ & $\begin{array}{l}225 \\
719\end{array}$ & $\begin{array}{l}26 \\
52\end{array}$ & $\begin{array}{l}14 \\
36\end{array}$ & 0.0 & $\begin{array}{l}14 \\
46\end{array}$ & $\begin{array}{l}14 \\
50\end{array}$ & 99 & $\begin{array}{l}\text { Plus/ } \\
\text { plus }\end{array}$ \\
\hline
\end{tabular}

PCR was done for the detection of virulence genes and 16srna sequencing for confirmed the E.coli that caused mastitis.

\section{Conclusion}

To conclude, the Coliform mastitis is caused by a group of coliform organisms E. coli is one of the most important bacterium of coliform group that causes mastitis in Cattle. E.coli isolates were isolated by culturing in Eosine Methylene blue agar and in Mac Conkey agar. The isolates were confirmed by different Biochemical Tests and Sugar fermentating Tests. E. coli was confirmed using PCR and 16srna sequencing were observed and it reveals the virulence of E. coli that caused mastitis The Ecoli sequence was submitted in genbank accessions no KC795687.

\section{References}

[1]. Adesiyun, A.A. 1994. Bacteriological quality and associated public health risk of pre- processes bovine milk in Irinidad. Intr. J. Food Microbiol., 21: $253-261$.

[2]. Adwan K., Abu-Hasan., Essawi T and Bdir M 2002. Isolation and characterization of Shiga toxigenic Escherichia coli strains from northern Palestine, Journal of Medical Microbiology, 51 (4); 332 - 335.

[3]. Ahmed, AM and S.S. Sailam 1991. Prevalence of E.coli serotypes in raw milk and some dairy products. Vet. Med.J., 25 : 93 - 97.

[4]. Alsemgeest S.P.M., kalsbeek H.C., Wensing Th., koeman J.P., van Ederen A.M. and Gruys E. 1994 Concentrations of serum amyloid A (SAA) and haptoglobin (Hp) as parameters of inflammatory diseases in cattle. Vet Q. $16: 21-23$

[5]. Anand, S.K, Shadma, Fatima, Joshi C.G and Purohit, J.H 2007. Molecular characterization of Escherichia coli using PCR single strand confirmation polymorphism analysis of $16 \mathrm{~S}$ rRNA gene, Indian Journal of Poultry Science, 41 (I) $1-5$.

[6]. Andrews, S.P.M., Horadagoda, A., Huslkamp-koch C.K., Tooten, P.C.J., Kim, D.H., Niewold, Th.A. and Gruys E. 1985 First evidence for the existence of multiple isoforms of bovine serum amyloid - A (apoSAA). Scand. J. Immunol. 41: 407 - 413.

[7]. Anietie E., R., J.P. Duguid, B.P. Marmion and R.H.A. Swain 1994... Identification of virulence attributes of gastrointestinal Escherichia coli isolated of veterinary significance vol. $1(2), 129-140$.

[8]. Barak, J.D., Sanannikone, K., Delwiche and M.J, Comparision 2005. of primers for the detection of pathogenic Escherichia coli using Real -time PCR, Letters in Applied Microbiology 41 (2) 112 - 118.

[9]. Bean. A, Williamson. J and Cursons R.T. 2004. Virulence Genes of Escherichia coli Strains Isolated from Mastitic Milk, Journal of Veterinary Madicine Series B. 51 (6), 285 - 287.

[10]. Boosman, R., Niewold, T. A., Mutsaers, C.W.A.A.M. and Gruys, E. 1989. Serum amyloid A concentrations in cows given endotoxin as an acute - phase stimulant. Am. J. Vet. Res. 50: $1690-1694$.

[11]. Bradley A.J. Bovine Mastitis: 2005 An Evolving Diease, The Veterinary Journal 164, 116 - 128.

[12]. Bradley A.J. and Green M.J. 2001. Adaptation of Escherichia coli to the bovine mammary gland. Journal of Clinical Microbiology. 39, No. $5,1845-1849$

[13]. Bradley A.J. and Green M.J. 2001. Adaptation of Escherichia coli to the bovine mammary gland. J. Clin. Microbiol. 39: 1845 1849

[14]. Bradley A.J. and Green M.J. 2000. A study of the incidence and significance of intramammary enterobacterial infections acquired during the dry period. J. Dairy Sci. 83: $1957-1965$.

[15]. Breazile, J.E. 1988. The physiology of stress and its relationship to mechanisms of disease and therapeuthics. Vet. Clin. North Am. Food Anim. Pract. 4. 441 - 480.

[16]. Burns, A.L. Ball, H.J. and Finlay, D.A. 1996 CNF producing Escherichia coli isolated from cattle in Northern Ireland. Vet Microbiol. 49: 235 - 241

[17]. Burvenich, C., Van merris, V., Merhzad, J., Diez-fraile, A. and Duchateau, L. 2003. Severity of E. coli mastitis is mainly determined by cow factors. Vet. Res. 34: $521-564$.

[18]. Carroll, E.J. Jain, N.C., Schalm, O.W. and Lasmanis, J. 1973. Experimentally induced coliform mastitis: Inoculation of udders with serum - sensitive and serum - resistant organisms. Am. J. Vet. Res. 34: $1143-1146$.

[19]. Casali. N and A. Preston 2005. Isolatio of Plasmid from E.coli by Alkaline Lysis. Methods in Molecular Biology, 23: 245 - 256

[20]. Cebra, C.K., Garry F.B. and Dinsmore, R.P. 1996. Naturally occurring acute coliform mastitis in Holstein cattle. J. Vet. Int. Med. 10: $252-257$

[21]. Childs, K.D, Simpson. C.A, Warren - Serna, W, Bellenger .G, Centrella. B. Bowling R. A, Ruby .J, Stefanek .j, Vote D. J, Choat .T, Scanga J. A, Sofos J.N, Smith G. C, and Belk K. E, 2006. Molecular Characterization of Escherichia coli 0157 :H7 Hide Contamination Routress; Feedlot to Harvest, Journal of food Protection, vol 69, (6) 40 - 1247.

[22]. China, B. and Goffaux, F. 1999. Secreation of virulence factors by Escherichia coli. Vet. Res. 30: 181 - 202

[23]. Chitrita DebRoy and Carol W. Maddox, 2001. identification of virulence attributes of gastrointestinal Escherichia coli isolates of veterinary significance, Animal Health Research Reviews, vol. 1 (2), 129 - 140. 